defects appears to occur with special frequency, in which the aetiology may well be different. Many of these have been described by Robertson et al. ${ }^{16}$

There is no evidence either from the data in this paper or from other published reports that the risk of hydrocephalus after a male proband is different for male or female sibs or that there is any differential sex risk except in the special sex linked syndrome.

I conclude that after a baby with congenital hydrocephalus has been conceived there is a substantially higher, but still low, risk to brothers and sisters alike of having either hydrocephalus or neural tube defects. The risk that uncomplicated hydrocephalus will affect the siblings of children with neural tube defects is of the same order. Consequently the two conditions, at least in a large proportion of cases, is probably of the same aetiology, and the same considerations should therefore be given to their possible primary prevention and to the need for appropriate antenatal tests to detect and deal with them according to the merits of the case.

I wish to thank the Richard Fund of Sheffield for secretarial help.

\section{References}

Lorber J. The family history of spina bifida cystica. Pediatrics 1965;35:589-95. 2 Carter CO, David PA, Laurence KM. A family study of major central nervous system malformations in south Wales. F Med Genet 1968;5:81-106.

Carter CO, Roberts F. The risk of recurrence after two children with central nervous system malformations. Lancet 1967;i:306-8.
- Smithells RW, Seller MJ, Harris R, et al. Further experience of vitamin supplementation for prevention of neural tube defect recurrences. Lancet 1983; ; $1027-3$

${ }^{5}$ Office of Population Censuses and Surveys Monitor. Congenital malformations.

London: HMSO, 1983. (MB3 83/5.)
Lorber J, De MC. Family history of congenital hydrocephalus. Dev Med Child

dwards JH. The syndrome of sex-linked hydrocephalus. Arch Dis Child $1961 ; 36$ : 486-93.

Weatherall JAC. A review of some effects of recent medical practices in reducing the numbers of children born with congenital abnormalities. Health Trends 1982 ; 14:85-8.

${ }^{9}$ Nevin NC. Prevention of neural tube defects in an area of high incidence. In: Dobbing J, ed. Prevention of spina bifida and other neural tube defects. London: Academic Press, 1983:127-53.

${ }^{1}$ Burton BK. Recurrence risks for congenital hydrocephalus. Clin Genet 1979;16: $47-53$.

"Adams C, Johnston WP, Nevin NC. Family study of congenital hydrocephalus. Dev Med Child Neurol 1982;24:493-8.

Record RG, McKeown T. Congenital malformations of the central nervous system. II. Reproductive history and familial incidence. British fournal of Social Medicine Borle A Sur 10

Sur l'étiologie de l'hydrocèphalie congenitale à propos d'un cas d'hydrocèphalie concordant chez de jumeaux univitellins. fournal of Human Genetics $1953 ; 2: 157$.

- Gellman V. Congenital hydrocephalus in monovular twins. Arch Dis Child 1959; 34:274.

${ }^{15}$ Smithells RW, D'Arcy EE, McAllister EF. The outcome of pregnancies before and after the birth of infants with nervous system malformations. Dev Med Child

${ }^{18}$ Robertson RD, Sarti DA, Brown WJ, Crandall BF. Congenital hydrocephalus in two pregnancies following the birth of a child with a neural tube defect: aetiology and management. F Med Genet 1981;18:105-7.

17 MacMahon B, Pugh TF, Ingalls TH. Anencephalus, spina bifida and hydrocephalus. British fournal of Preventive and Social Medicine 1953;7:211-9.

Willamson EM. Incidence and family aggregation of major congenital malformation

列

Hungary. British fournal of Preventive and Social Medicine 1970;24:205-22.
Bay C, Kerzin L, Hall BD. Recurrence risk in hydrocephalus. Birth Defects 1975; $15(5 \mathrm{c}): 95-105$

${ }^{21}$ Howard FM, Till K, Carter CO. A family study of hydrocephalus resulting from aqueduct stenosis. F Med Genet 1981;18:252-5.

(Accepted 15 fune 1984)

뭉

要

\title{
Comparison of reliability of tests to distinguish upper from lower urinary tract infection
}

\author{
G H C SCHARDIJN， L W STATIUS VAN EPS，W PAUW，C HOEFNAGEL，W J NOOYEN
}

\begin{abstract}
The results of scintiphotography with gallium-67 $\left({ }^{67} \mathrm{Ga}\right)$, renography with technetium-99m diethylene triamine penta-acetic acid, immunofluorescence of antibody coated bacteria, and determination of renal $\beta_{2}$ microglobulin excretion were compared in 19 patients with upper and 15 patients with lower urinary tract infection. All patients with acute pyelonephritis showed an appreciable unilateral or bilateral uptake of ${ }^{67} \mathrm{Ga}$ and an increased excretion of $\beta_{2}$ microglobulin, whereas immunofluorescence of antibody coated bacteria yielded positive results in only 10 . In patients with lower urinary tract infections excretion of $\beta_{2}$ microglobulin and uptake of ${ }^{67} \mathrm{Ga}$ were always normal, whereas immunofluores-
\end{abstract}

Slotervaart Hospital, 1066 EC Amsterdam, The Netherlands G H C SCHARDIJN, MD

L W STATIUS VAN EPS, head of department of internal medicine W PAUW, microbiologist

Antoni van Leeuwenhoek Hospital, 1066 CX Amsterdam, The Netherlands

C A HOEFNAGEL, physician in nuclear medicine

W J NOOYEN, PHD, biochemist

Correspondence to: Dr L W Statius van Eps. cence of antibody coated bacteria was positive in three cases.

Scintiphotography with ${ }^{67} \mathrm{Ga}$ and determination of renal $\beta_{2}$ microglobulin excretion are currently the most reliable non-invasive methods of detecting acute pyelonephritis.

\section{Introduction}

About $20 \%$ of patients admitted to dialysis units with end stage kidney disease have a history of recurrent upper urinary tract infection. ${ }^{1}$ Moreover, asymptomatic bacteriuria correlates with a shortened life expectancy. The problem of diagnosing and localising renal infection has challenged many clinicians, and many diagnostic procedures and methods have been suggested. ${ }^{2}$ Bilateral ureteric catheterisation and bladder washout procedures are currently considered to be the most specific. These methods are, however, time consuming and have the risk of introducing new pathogenic micro-organisms. They may also produce false negative results in cases of obstructive uropathy or as a result of previously administered antibiotics. Intravenous urography is of limited value, especially in the case of acute pyelonephritis. ${ }^{3-5}$

Scintiphotography with gallium-67 $\left({ }^{67} \mathrm{Ga}\right)$ has been reported by several investigators as a useful method for diagnosing renal infections. ${ }^{6-10}$ We have reported that upper and lower urinary tract infections may be distinguished by estimating the excretion of urinary $\beta_{2}$ microglobulin. ${ }^{11}$ False positive results may be obtained in patients with pre-existent tubular dysfunction and 
false negative results if the urinary $\mathrm{pH}$ is lower than 6 . In the present study we compared the results of scintiphotography with ${ }^{6:} \mathrm{Ga}$, renography with technetium-99m $\left({ }^{99 \mathrm{~m}} \mathrm{Tc}\right)$ diethylene triamine penta-acetic acid (DTPA), determination of renal excretion of $\beta_{2}$ microglobulin, and immunofluorescence of antibody coated bacteria in patients with acute pyelonephritis or lower urinary tract infection.

\section{Subjects and methods}

We studied 34 patients and 44 controls, all of whom had been admitted to hospital. Nineteen of the patients were suffering from acute pyelonephritis and 15 from a lower urinary tract infection. Only patients with urinary tract infections underwent scintiscanning with ${ }^{67} \mathrm{Ga}$, but all patients and controls underwent intravenous urography. The controls had no signs of urinary tract infection or impaired renal function.

Acute pyelonephritis was diagnosed according to the following criteria: (1) clinical and physical findings typical of acute renal inflammation; (2) positive cultures of blood and urine with the same micro-organism; (3) abnormal results of intravenous urographyacute pyelonephritis can cause the following radiographic findings: dilated and distorted pelvicalyceal structures, non-obstructive ureteric dilatation, diminished concentration of contrast material, a delayed pyelogram, renal enlargement, and a prolonged or diminished visualisation of the kidney or kidneys; and (4) positive results of scintiphotography with ${ }^{6}$ ' Ga. Only patients who met at least three of these criteria were considered to have pyelonephritis. Patients with lower urinary tract infection had a typical history of acute cystitis and yielded negative results to intravenous urography.

Scintiphotography with ${ }^{67} \mathrm{G} a-{ }^{67} \mathrm{Ga}$ was given intravenously in a dose of $74 \mathrm{MBq}(2 \mathrm{mCi})$. Posterior and anterior abdominal scans were obtained by collecting counts over five minutes in a 256256 matrix 48 hours after injection and, in case of faint renal accumulation, again after 96 hours. A $\because$ camera with a large field of view was used equipped with a medium energy collimator using three $(93,185$, and $300 \mathrm{keV})$ of the four photopeaks of ${ }^{67} \mathrm{Ga}$, being responsible for 41,23 , and $18^{\prime \prime}$ " of the total counts respectively. Radioactivity over the heart or aorta as blood pools was used as the reference point. After scintiscanning with ${ }^{17} \mathrm{Ga}$ the patients were given $185 \mathrm{MBq}(5 \mathrm{mCi}){ }^{99_{\mathrm{m}}} \mathrm{Tc}$ DTPA intravenously, while lying in the same position. With the collimator adjusted, the energy peak of $140 \mathrm{keV}$ was used for the renography. As the emission of gallium influences the curves of the technetium counts over the kidneys the images of the kidneys were of more importance than the curves for the assessment of the renal function and for the detection of postrenal obstruction. The analyses were done with an MDS A two system computer, which enabled us to mark the regions of interest. With this method, the kidney margins were projected over the accumulation of ${ }^{67} \mathrm{Ga}$ to ensure that the increased uptake of ${ }^{67} \mathrm{Ga}$ was actually localised in the kidneys.

Excretion of $\beta_{2}$ microglobulin- $\beta_{2}$ microglobulin was assayed by a solid phase radioimmunoassay (Pharmacia, Uppsala). We studied the stability of $\beta_{2}$ microglobulin under conditions of different urinary $\mathrm{pH}$ at a temperature of $37 \mathrm{C}$. The estimation of $\beta_{2}$ microglobulin concentration in the urine was irreversibly influenced after incubation for two

Results of scintiphotography with ${ }^{67} \mathrm{Ga}$, renography with ${ }^{99 \mathrm{~m} T C}$ DTPA, immunofluorescence of antibody coated bacteria, and determination of urinury $\mathrm{B}_{2}$ microglobulin excretion in three groups of subjects

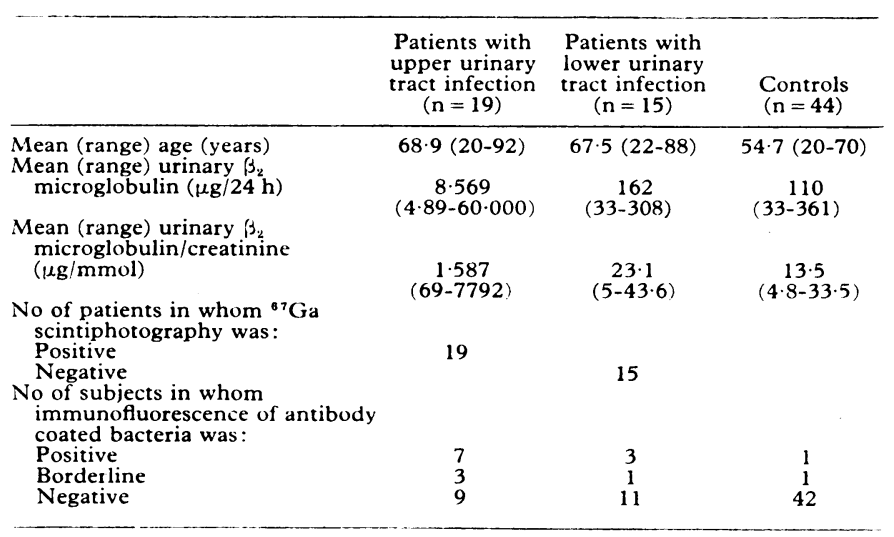

hours at a pH lower than $11 .{ }^{1}$ To prevent this we gave our patients $4 \mathrm{~g}$ sodium bicarbonate the evening before the experiment and another $4 \mathrm{~g}$ during the day on which urine was collected. Only specimens with $\mathrm{pH} \geqslant 6$ were assayed.

Immunofluorescence of antibody coated bacteria-Specimens of fresh midstream urine were spun at 4000 revolutions per minute for 10 minutes. The urine sediment was washed twice in a buffered sodium chloride solution $\mathrm{pH} 7 \cdot 3$, after which $0.2 \mathrm{ml}$ fluorescein-conjugated antihuman immunoglobulin $\mathrm{G}$ of horse origin was added. Incubation was for 30 minutes at $37^{\circ} \mathrm{C}$. After incubation the urine sediment was washed twice again in the buffered saline solution. The urine was then investigated immediately with a fluorescence microscope with a magnification of $\times 400$. Fluorescence was assessed on a five point scale varying from 0 (no fluorescence) to 4 (strong fluorescence). Furthermore, the result was considered to be positive if at least half, and borderline if at least a quarter, of the bacteria were coated with immunoglobulin.

\section{Results}

All patients with acute pyelonephritis yielded positive results to scintiphotography with ${ }^{67} \mathrm{Ga}$ and showed raised excretion of urinary $\beta_{2}$ microglobulin, whereas all patients with lower urinary tract infection yielded negative results to scintiphotography with ${ }^{67} \mathrm{Ga}$ and showed normal excretion of urinary $\beta_{2}$ microglobulin (table). There was no overlap in urinary excretion of $\beta_{2}$ microglobulin between patients with upper and those with lower urinary tract infection (fig 1).

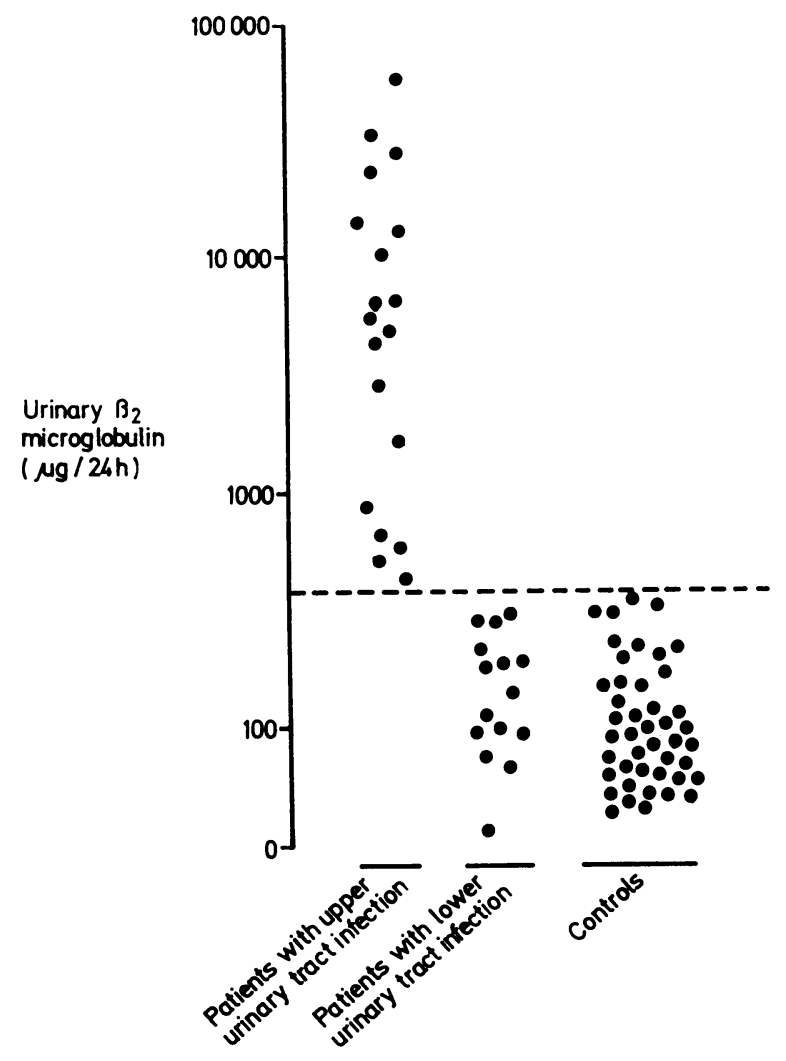

FIG 1-Urinary excretion of $\beta_{2}$ microglobulin in 19 patients with acute pyelonephritis, 15 patients with lower urinary tract infections, and 44 controls.

Immunofluorescence of antibody coated bacteria yielded positive results in only 10 patients with acute pyelonephritis, whereas three patients with lower urinary tract infection and one of the controls yielded a definite positive result. In several patients with upper urinary tract infection an increased uptake of ${ }^{67} \mathrm{Ga}$ was accompanied by a decreased visualisation of ${ }^{99_{\mathrm{m}}}$ Tc DTPA, suggesting decreased function of the inflamed kidney (fig 2) partially explained by a diminished renal blood flow. Moreover, the delayed renal localisation of ${ }^{67} \mathrm{Ga}$ correlates well in most patients with unilateral pyelonephritis with overt tenderness of the renal region. 


\section{Discussion}

${ }^{67} \mathrm{Ga}$ is currently used widely in localising tumours and detecting infectious lesions, particularly abscesses. It is a $\gamma$ emitting radionucleide with a physical half life of 72 hours. After injection it is bound to plasma transferrin, polymorphonuclear leucocytes, and lymphocytes. Binding to erythrocytes is negligible. ${ }^{12}$ It is transported to the whole body, and high concentrations are found in the liver, spleen, skeleton, kidneys, and intestine.

The reason for the high concentration of ${ }^{67} \mathrm{Ga}$ in inflammatory lesions is still not certain. It may be explained by an increased affinity of ${ }^{67} \mathrm{Ga}$ to polymorphonuclear leucocytes, lymphocytes, bacteria, or acute phase proteins like lactoferrin. ${ }^{12-15}$ An abnormal renal retention of ${ }^{67} \mathrm{Ga}$ has been documented in pyelonephritis, Wegener granulomatosis, vasculitis, renal vein thrombosis, renal and perinephric abscesses, primary renal nucleated cells and is part of the HLA complex on the cell surface. The daily production is constant in healthy subjects and increased in many diseases, especially in those accompanied by activation of lymphocytes. The small molecule, which leaves the body exclusively by glomerular filtration, is filtered easily through the glomerular membrane, almost completely reabsorbed $(99.9 \%)$, and metabolised by the proximal tubule. In proximal tubular dysfunction, like pyelonephritis, the reabsorption of $\beta_{2}$ microglobulin is disturbed. As a consequence, the renal excretion of $\beta_{2}$ microglobulin is increased $(>370 \mu \mathrm{g} / 24 \mathrm{~h})$ and returns to normal when the tubular function improves-for example, during treatment of the infection with appropriate antibiotics. Special precautions should be taken to avoid the production of urine with a $\mathrm{pH}$ lower than 6 as $\beta_{2}$ microglobulin loses its antigenicity irreversibly in urine with a pH lower than 6 , even in the short period before voiding. Our results confirm the value of

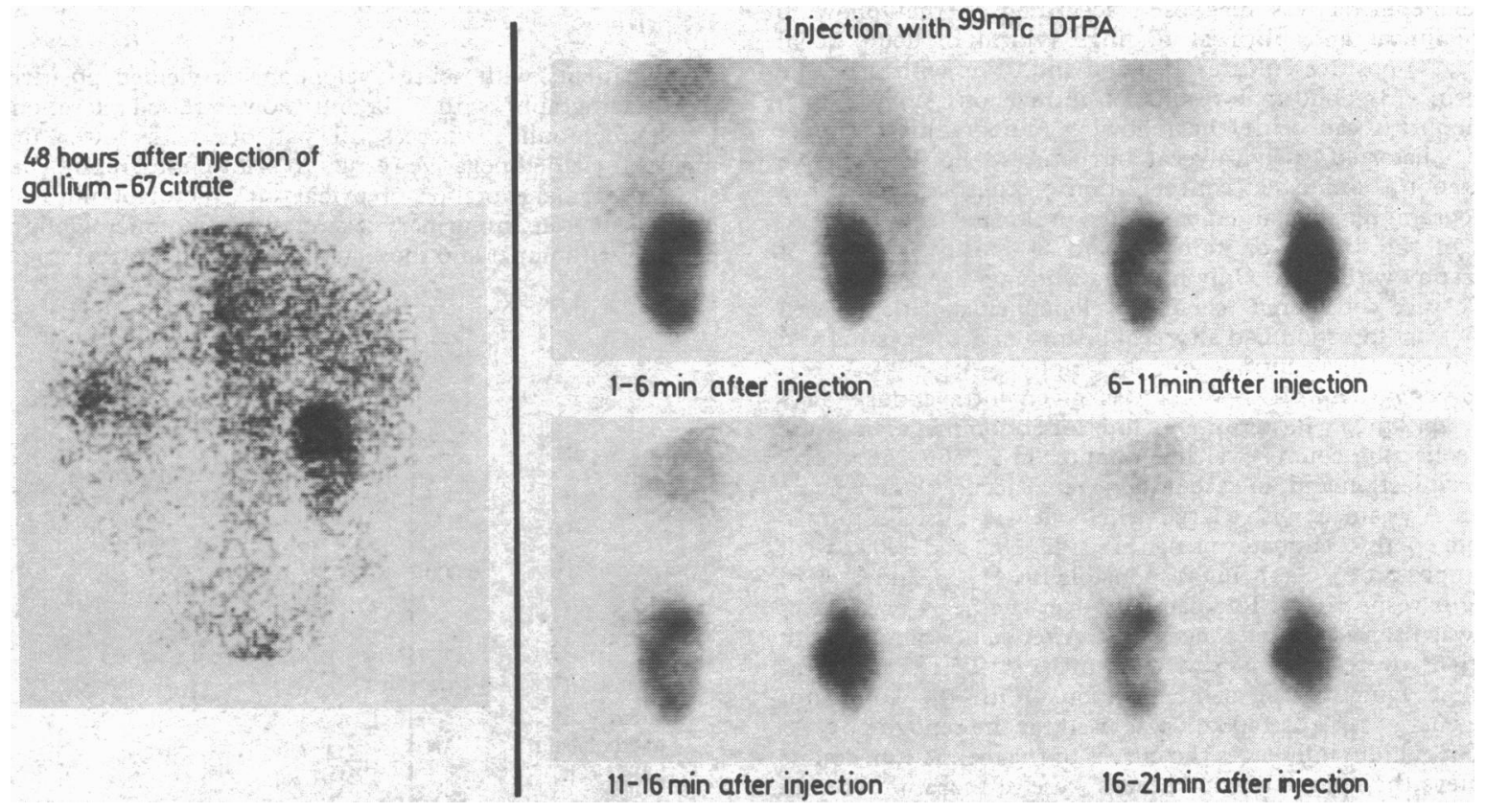

FIG 2-Results of isotope scanning in an 81 year old man with pyelonephritis of the right kidney and urosepsis caused by Escherichia coli, showing (left) intense accumulation of ${ }^{67} \mathrm{Ga}$ in the upper pole of the right kidney accompanied (right) by decreased activity of ${ }^{99}$ Tc DTPA over the same region and a delayed excretion of ${ }^{99}$ Tc DTPA of the right kidney. (Posterior view in all cases.)

tumours, amyloidosis, and sometimes in non-infectious interstitial nephritis. ${ }^{816-18}$

Ormrod et al found an increased uptake of ${ }^{67} \mathrm{Ga}$ in the kidneys of rats with experimental unilateral pyelonephritis caused by a direct inoculation with Escherichia coli. ${ }^{19}$ The accumulation of ${ }^{67} \mathrm{Ga}$ correlated well with gross and histopathological findings in the pyelonephritic kidneys. The ${ }^{67} \mathrm{Ga}$ activity over these kidneys increased throughout the first seven days, but there was no significant difference in activity between 14 and 28 days.

We found an increased accumulation of ${ }^{67} \mathrm{Ga}$ in all patients with acute pyelonephritis. In several patients with unilateral pyelonephritis the increased uptake of ${ }^{67} \mathrm{Ga}$ was accompanied by a decreased activity of ${ }^{9} \mathrm{~T}$ Tc DTPA over the same kidney, while the contralateral kidney that was not affected yielded normal results to renography without an increased uptake of ${ }^{67} \mathrm{Ga}$. Our findings are similar to those of Biskjaer $e t \quad a l^{20}$ and Handmaker, ${ }^{10}$ who observed in several patients with pyelonephritis a decreased renal radioactivity using renal cortical radiopharmaceutical agents like ${ }^{99} \mathrm{Tc}$ succimer or ${ }^{90} \mathrm{Tc}$ glucoheptate. Handmaker suggested that these observations can be explained by peritubular oedema, increased interstitial pressure, and plugs of cellular debris within the tubules as were found in pyelonephritis. ${ }^{10}$

$\beta_{2}$ microglobulin is a protein with a light molecular weight (11 800 daltons). It is produced by the ribosomes of most determining excretion of $\beta_{2}$ microglobulin to diagnose acute renal infections. Moreover, follow up studies can be used to control the efficacy of drug treatment and to detect recurrences.

In 1974 Thomas $e t$ al showed the binding of antibodies on the surface of bacteria with a direct immunofluorescence test. ${ }^{21}$ They found a correlation between a positive result to the test and upper urinary tract infection and between a negative result and lower urinary tract infection. False positive results have, however, been reported in proteinuria, asymptomatic bacteriuria, acute haemorrhagic cystitis, prostatitis, and cystitis. ${ }^{21}{ }^{22}$ In acute pyelonephritis positive results may be found in $62-69 \%$ of cases. ${ }^{21}{ }^{23}{ }^{24}$ Our results of immunofluorescence of antibody coated bacteria in patients with acute pyelonephritis confirm the conclusion of Mundt and Polk that the test does not have a role in the management of patients with urinary tract infection because of its low sensitivity (83.1\%) and specificity (76.7\%). ${ }^{25}$ Among the possible non-invasive techniques, scintiphotography with ${ }^{67} \mathrm{Ga}$ and determination of excretion of urinary $\beta_{2}$ microglobulin are currently the most appropriate for the diagnosis of renal inflammation. Moreover, serial determinations of urinary $\beta_{2}$ microglobulin excretion are useful in controlling the efficacy of treatment with antibiotics.

GHC was supported by a grant from the Netherlands Kidney Foundation. We thank $M$ Ruijters for typing the manuscript. 


\section{References}

Anonymous. Bacteriuria-when does it matter ? [Editorial]. Lancet 1979 ;ii:1166-7. ass EH. The search for asymptomatic pyelonephritis. N Engl f Med 1972;287 563-4.

Davidson AJ, Tainer LB. Urographic and angiographic abnormalities in adult onset acute bacterial nephritis. Radiology 1973;106:249-56.

Cameron DD, Azimi F. The value of excretory urography in the diagnosis of acute pyelonephritis. 3 Urol $1974 ; 112: 546-9$

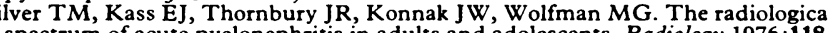
65-71.

" Kessler WO, Gittes RF, Hurwitz SR, Green J. Gallium-67 scans in the diagnosis of pyelonephritis. West $\mathcal{Y}$ Med $1974 ; 121: 91-3$.

Hurwitz SR, Kessler WO, Alazraki P, Ashburn WK. Gallium-67 imaging to localize urinary tract infections. Br $\mathcal{F}$ Radiol $1976 ; 49: 156-60$.

* Kumar B, Coleman RE. Significance of delayed 67-Ga localization in the kidneys. f Nucl Med 1976;17:872-5.

Mendez G Jr, Morillo G, Alonso M, I sikoff MB. Gallium 67 radionuclide imaging

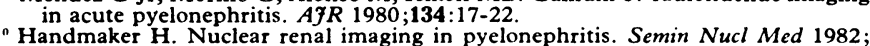

12:246-53.
"Schardijn G, Statius van Eps LW, Swaak AJG, Kager JCGM, Persijn JP. Urinary $\beta_{2}$-microglobulin in upper and lower urinary tract infections. Lancet 1979; i:

Tsan MF, Chen WY, Scheffel U, Wagner HN. Studies on gallium accumulation in inflammatory lesions: gallium uptake by human polymorphonuclear leuko-
1: Hoffer PB, Huberty J, Khayam-Bashi $H$. The association of Ga-67 and lactoferrin. f Nucl Med 1977;18:713-7

" Menon S, Wagner HN, Tsan MF. Studies on gallium accumulation in inflammatory lesions. Uptake by Staphylococcus aureus. $7 \mathrm{Nucl}$ Med 1978;19:44-7.

15 Tsan MF. Studies on gallium accumulation in inflammatory lesions. Roles of polymorphonuclear leukocytes and bacteria. $\mathcal{f}$ Nucl Med 1978;19:492-5.

16 Bekerman C, Vyas MI. Renal localization of gallium 67 citrate in renal amyloidosis. f Nucl Med 1976;17:899-901.

Myerson PJ, Myerson DA, Spencer RP, Prokop E. ${ }^{67} \mathrm{Ga}$-citrate identification of inflammation in the perirenal space. Clin Nucl Med 1978;3:434-6.

${ }^{8}$ Graham G, Lundy MM, Moreno AJ. Failure of gallium-67 scintigraphy to identify reliably noninfectious interstitial nephritis. F Nucl Med 1983;24:568-70. rmrod D, Miller T, Stewart E. Detection of renal infection by gallium-67 localization. An experimental evaluation. Kidney Int 1977;12:157-63

99mar N, Thelle T. Pyelonefritiske parenchymdefekter hos born bedomt ved Tc-DMSA nyrescintigrafi og iv urografi. Ugeskr Laeger 1983;145:1604-6.

Thomas V, Shelokov A, Forland $M$. Antibody-coated bacteria in the urine and the site of urinary-tract infection. N Engl f Med 1974;290:588-90.

:2 Rumans LW, Vosti KL. The relationship of antibody coated bacteria to clinical syndromes. Arch Int Med 1978;138:1077-81.

3 Thomas VL, Forland $M$. Antibody coated bacteria in urinary tract infections. Kidney Int 1982;21:1-7.

24 Ratner JJ, Thomas VL, Sanford BA, Forland M. Bacteria-specific antibody in the urine of patients with acute pyelonephritis and cystitis. $\mathcal{F}$ Infect Dis $1981 ; 143$ :

Mundt KA, Polk BF. Identification of site of urinary tract infections by antibody coated bacteria assay. Lancet 1979 ;ii:1172-5.

(Accepted 2 May 1984)

\section{SHORT REPORTS}

\section{Role of glucocorticoids in management of malignant hypercalcaemia}

Glucocorticoids are commonly prescribed in malignant hypercalcaemia due to carcinoma' despite conflicting evidence on their efficacy. ${ }^{2}$ We examined the effects of prednisolone on hypercalcaemia in patients with solid tumours.

\section{Patients, methods, and results}

We studied 28 patients with hypercalcaemia associated with solid tumours (breast, 17 patients; bronchus, six; cervix, four; hypernephroma, one) All but four patients had scintigraphic or radiographic evidence of metastases of bone. All patients were treated continuously with intravenous saline (4-6 portant component of management. ${ }^{5}$ As the efficacy of rehydration is commonly underestimated additional agents are often prescribed. Any hypocalcaemic response then observed may be due to the additional treatment rather than to rehydration. Our study suggests that the use of glucocorticoids to treat hypercalcaemia due to solid tumours is ineffective and that the responses observed were entirely attributable to rehydration. As steroids are not free of risk and have catabolic effects on bone we now avoid giving them to patients with malignant hypercalcaemia. Corticosteroids remain useful, however, in the treatment of hypercalcaemia due to other causes, particularly myeloma, sarcoidosis, and vitamin $\mathrm{D}$ toxicity. ${ }^{2}$

Mean (SEM) serum calcium and creatinine concentrations in patients with hyperglycaemia treated with rehydration alone or combined with corticosteroids

\begin{tabular}{|c|c|c|c|c|c|c|}
\hline & \multicolumn{3}{|c|}{ Saline alone } & \multicolumn{3}{|c|}{ Saline + steroids } \\
\hline & Day 0 & Day 3 & Day 7 & Day 0 & Day 3 & Day 7 \\
\hline $\begin{array}{l}\text { Adjusted serum calcium }(\mathrm{mmol} / \mathrm{l}) \\
\text { Serum creatinine }(\mu \mathrm{mol} / \mathrm{l})\end{array}$ & $\begin{array}{l}3.49(0 \cdot 13) \\
0.119(9 \cdot 8)\end{array}$ & $\begin{array}{l}3 \cdot 21(0 \cdot 13)^{* *} \\
108(13 \cdot 3)^{* * *}\end{array}$ & $\begin{array}{l}2 \cdot 86(0 \cdot 16)^{*} \\
80(10)^{*}\end{array}$ & $\begin{array}{l}3 \cdot 56(0 \cdot 17) \\
148(22)\end{array}$ & $\begin{array}{l}3.24(0 \cdot 12)^{* *} \\
131(27)^{*}\end{array}$ & $\begin{array}{l}3.02(0.08)^{* *} \\
103(13)^{* * *}\end{array}$ \\
\hline
\end{tabular}

Significance of changes induced by treatment: ${ }^{*} p<0.02 ; * * p<0.01$

Conversion: SI to traditional units-Calcium: $1 \mathrm{mmol} / \mathrm{l}=4 \mathrm{mg} / 100 \mathrm{ml}$. Creatinine: $1 \mu \mathrm{mol} / 1 \approx 11.3 \mu \mathrm{g} / 100 \mathrm{ml}$.

litres daily), and 15 were additionally treated with prednisolone $(20-60 \mathrm{mg}$ daily by mouth). None of the patients received diuretics, chemotherapy, or other agents likely to affect the serum calcium concentration. Venous blood samples obtained before treatment and at three and seven days were analysed for serum calcium, creatinine, and albumin concentrations with a Technicon SMAC AutoAnalyzer. Calcium values were adjusted to an albumin concentration of $42 \mathrm{~g} / 1$. The significance of changes between mean values was assessed with a two tailed Wilcoxon's rank sum test for paired observations. Results are expressed as means (SEM).

Patients given saline alone and those given saline and prednisolone were similar with regard to age (64 (3) $v 51$ (3) years); initial serum calcium concentration $(3.49(0.13) v 3.56(0.17) \mathrm{mmol} / 1(14(0.5) v 14.0 .7) \mathrm{mg} / 100 \mathrm{ml}))$; serum albumin concentration $(35(1) v 35(1) \mathrm{g} / 1)$; and serum creatinine concentration $(119(10) v 131(27) \mu \mathrm{mol} / 1(1.3(1 \cdot 1) v 1.5(0.3) \mathrm{mg} / 100 \mathrm{ml}))$. Treatment with saline alone induced a significant fall in serum calcium concentrations (mean decrease $0.40(0.12) \mathrm{mmol} / \mathrm{l}(1.6(0.5) \mathrm{mg} / 100 \mathrm{ml})$ at seven days), which was associated with a significant fall in serum albumin and creatinine concentrations (table). The addition of prednisolone to the intravenous fluid regimen did not confer any additional benefit.

\section{Comment}

Dehydration helps to perpetuate or aggravate hypercalcaemia of whatever origin, ${ }^{34}$ and, therefore, attention to fluid balance is an im-
RESG is supported by the Leukaemia Research Fund.

Anonymous. Management of severe hypercalcaemia [Editorial]. Br Med $\mathcal{F} 1980$;

280:204-5.
Mundy GR, Martin TJ. The hypercalcemia of malignancy: pathogenesis and management. Metabolism 1983;31:1247-75.

Parfitt AM. Equilibrium and disequilibrium hypercalcaemia. New light on an

- Kanis JA, Cundy T, Heynen G, Russell RGG. The pathophysiology of hypercalcaemia. Metab Bone Dis Relat Res 1980;2:151-9.

Hosking DJ, Cowley A, Bucknall CA. Rehydration in the treatment of severe hypercalcaemia. $Q \mathcal{f}$ Med $1981 ; 50: 473-81$.

(Accepted 8 May 1984)

Department of Human Metabolism and Clinical Biochemistry, University of Sheffield Medical School, Sheffield S10 2RX

RICHARD C PERCIVAL, FRCS, Wellcome surgical research fellow

ASHLEY J P YATES, MRCP, Medical Research Council clinical research fellow

RICHARD E S GRAY, MA, MRCP, research fellow

FRANK E NEAL, FRCR, consultant radiotherapist and oncologist

A ROBERT W FORREST, MRCPATH, consultant chemical pathologist

JOHN A KANIS, MRCP, reader

Correspondence to: Dr J A Kanis. 